\title{
Start with the End in Mind: Frameworks for Designing a Socially Inclusive School Environment
}

\author{
Sacha Cartagena, Lindsey Pike \\ College of Community Innovation and Education \\ University of Central Florida, USA
}

\begin{abstract}
The authors of this conceptual paper propose a framework for creating a socially inclusive school environment using the backward design method, with considerations for social-emotional learning competencies and Universal Design for Learning. Inclusive education became an international priority since 1994 when the Salamanca Statement was signed at the World Conference on Special Needs Education. While many countries have progressed to more inclusive models of education, societal constructs, including the medical model of disability, contribute to the continued barriers of full inclusion. When designing educational environments, education providers should consider selecting desired outcomes based on the social-emotional learning framework developed by the Collaborative for Academic, Social, and Emotional Learning (CASEL). Furthermore, the implementation of Universal Design for Learning principles ensure accessibility and engagement of all student learners regardless of disability or diversity. By using backward design to plan ahead and intentionally design educational environments to be inclusive and support the social-emotional needs of all students, education providers can construct new realities and dismantle disabling barriers that were first constructed by society.
\end{abstract}

\section{Introduction}

Children with disabilities have been historically segregated from their peers into institutions, hospitals, and separate facilities based on apparent differences and disabilities [1]. With the inception of the IQ test by Alfred Binet and Theodore Simon in France in the early 20th century [2], students who performed below their peers but did not "appear" to have a disability were also identified and often separated. Although Binet himself published his thoughts on the limitations of the IQ test and cautioned against its definitive use, it became an instrument often used to segregate, discriminate, and even exterminate as in the Eugenics movement
[1][2][3]. For decades after its development and use, students around the world who did not learn the same way or at the same speed as their peers and underperformed on assessments like the IQ test were relegated to spaces away from general society. Many were forgotten in institutions, contained and receiving no education at best, subject to abuse, experimentation, and deplorable living conditions at worst. As the 20th century moved forward, views slowly shifted and schools for children with diverse abilities, albeit rare, were established in many western nations. Despite progress, it was not until the 1990's that a universal declaration of the importance for inclusive education was pushed forward for the children of the world. For the purpose of this article, the authors define inclusion or inclusive education as an educational system or model in which students with disabilities or other forms of diversity are educated in the same environment as general education students or students without a disability. The 1994 Salamanca Statement from the United Nations represents the consensus of 92 nations recognizing inclusive education as "the most effective means of combating discriminatory attitudes... and improve the efficiency and ultimately the costeffectiveness of the entire education system" [4]. In the decades since, a variety of national and international organizations have undertaken the mission of advancing the cause of inclusive education around the world and broadening the understanding of the essential elements which create truly inclusive settings. One of the more recent international roadmaps is the Education 2030 Incheon Declaration and Framework for Action from the United Nations Educational, Scientific and Cultural Organization [4]. The framework and action plan put forth emphasizes inclusion and equity as the cornerstone for quality education. The need to remove all exclusionary barriers in access, participation, learning processes, and education outcomes are also underscored. The recent Global Education Monitoring Report published by UNESCO [6] details the progress and challenges in pursuit of inclusive education around the globe. Perhaps one of the most important points 
made in this report is a renewed emphasis that truly inclusive education does not only provide for a child's abilities, but also diversity in their cultural and ethnic backgrounds, experiences, and personal characteristics.

\section{Inclusion in the United States}

Within the United States, the modern movement for inclusive education gained momentum during the civil rights movement, the disability rights movement, and the accompanying mid-century legislation. The cornerstone Brown v. Board of Education case [7], though dealing with the issue of racial segregation, resulted in a ruling that separate education is inherently unequal. Around this time, the appalling conditions of institutions and schools for people with disabilities and mental health conditions were gaining the public's attention [8]. The passing of the Rehabilitation Act of 1973 [9] and the Education for all Handicapped Children Act of 1975 [10] cleared the path for the Individuals with Disabilities Education Act (IDEA) [11] and its reauthorizations into the new millenia. As educational rights for students with disabilities expanded throughout the U.S. so did efforts for inclusive education. However, the current state of inclusive education in the U.S. is not consistent as state and local district-level education agencies have authority to implement federal policies in the manner which they see most appropriate for their communities. This system of government has resulted in a range of models for inclusion with few districts or individual schools striving towards full inclusion [12]. Perhaps some of the biggest barriers to implementing inclusive education in the U.S. are the divided opinions on whether authentic inclusion [13] is possible or sustainable, education policies which require educational placement decisions prior to attempts at inclusion [14], and lack of resources and training for educators and administrators to design and facilitate inclusive classrooms and schools [4].

Varying perspectives on disability translate to different models and definitions of inclusive education. The IDEA mandates the use of the least restrictive environment (LRE) which states that "to the maximum extent appropriate" students with disabilities must be educated with students without disabilities [11]. The regulations further specify that separate classes or separate schooling are permissible only in the event that the severity of the disability is such that education occurring with the general population cannot be achieved satisfactorily, even with supplementary aids and services. The full-inclusion movement has interpreted LRE to mean that all students, regardless of severity of disability, should receive education in the same setting as their general education peers with exceptions made for only the most extreme cases. Proponents for full inclusion posit that the barriers to learning often experienced by students with significant disabilities are societal constructs and when these constructs are addressed with inclusive teaching practices then students with and without disabilities are able to thrive in the same learning environment [14].

\subsection{Models of disability and broadening our definition of diversity}

Inclusive education is predicated on the social model of disability which does not recognize disability as a deficit within the individual, but a function of the society and systems they engage in [15][16]. The medical model of disability perceives limitations on human function, resulting in treatments, programs, medications, or technologies as methods to 'fix' the individual for participation in society. The social model places the responsibility on society to reimagine and rebuild in a way that is inclusive for all. When working to build and facilitate inclusive classrooms and inclusive schools, a shift in thinking about disability is integral to breaking down barriers and divides in learning [13]. Fully inclusive programs begin with all children in the same classroom regardless of diversities and differences, molding the classroom and instruction around a broad spectrum of student abilities and preferences [14]. Each model has its proponents and opponents, as well as barriers and benefits to implementation. As mentioned earlier, differing visions on inclusion and standards to achieve it contribute to the barriers of universalizing inclusive education [13]. Policy, resources, values, and culture all play a role in what inclusion looks like in each school, district, and country, and therefore it is critical for decision-makers to remain grounded in the broad, intersectional vision of inclusive education put for by UNESCO and other educational leaders [6].

Embedded within the international call for inclusive education are three justifications for the movement: educational, social, and economic [17]. Each of these justifications highlights the benefits to general society of prioritizing inclusive education. Firstly, educating all students together requires the development of multiple ways of teaching to meet individual differences, which benefits all children [18]. Inclusive schools also support the de-stigmatization of difference and decreases discrimination in society [6]. Developing inclusive schools that provide education for all students is less costly than a system with different types of specialized schools for different groups [12][19]. In understanding the advantages of inclusive education, the task becomes setting the definition of what constitutes "inclusive" in order to achieve it. As 
suggested by international research and reform on the topic, inclusive education should have a broad definition containing multiple aspects of diversity, learning, and activity within the classroom and apply to academics and social-emotional learning [18][5].

\section{Social-emotional learning}

Social-emotional learning is defined as the process of learning skills related to identifying and managing one's own emotions as well as developing and maintaining social relationships [20]. Research indicates there are many benefits to social-emotional learning that include an increase in academic and behavioral performance. The Collaborative for Academic, Social, and Emotional Learning (CASEL) has developed a framework that outlines the core competencies of social-emotional learning, displayed in Table 1. This framework addresses social-emotional learning at the classroom, school, and community-wide levels through intentional classroom instruction, schoolwide policies, and purposeful and authentic partnerships with community stakeholders [20]. The emphasis on relationship-building and fostering a supportive community promotes an environment that is inclusive of students from all backgrounds and forms of diversity. This framework helps support social inclusion which then provides opportunities for observational learning and social reinforcement [21]. For students with disabilities, especially students with more severe disabilities who are typically educated in a segregated environment, socially inclusive environments may be the only opportunity to benefit from observational learning [21].

Table 1. SEL core competencies, definitions, and related skills, adapted from CASEL [20]

SEL Core

Competencies

\begin{tabular}{|c|c|c|}
\hline Self-Awareness & $\begin{array}{l}\text { Self-awareness: The abilities to understand one's own } \\
\text { emotions, thoughts, and values and how they influence } \\
\text { behavior across contexts. This includes capacities to } \\
\text { recognize one's strengths and limitations with a well- } \\
\text { grounded sense of confidence and purpose. }\end{array}$ & $\begin{array}{l}\text { Identifying emotions } \\
\text { Accurate self-perception } \\
\text { Recognizing strengths } \\
\text { Self-confidence } \\
\text { Self-efficacy }\end{array}$ \\
\hline Self-Management & $\begin{array}{l}\text { Self-management: The abilities to manage one's emotions, } \\
\text { thoughts, and behaviors effectively in different situations } \\
\text { and to achieve goals and aspirations. This includes the } \\
\text { capacities to delay gratification, manage stress, and feel } \\
\text { motivation and agency to accomplish personal and } \\
\text { collective goals. }\end{array}$ & $\begin{array}{l}\text { Impulse control } \\
\text { Stress management } \\
\text { Self-discipline } \\
\text { Self-motivation } \\
\text { Goal setting } \\
\text { Organizational skills }\end{array}$ \\
\hline Social Awareness & $\begin{array}{l}\text { Social awareness: The abilities to understand the } \\
\text { perspectives of and empathize with others, including those } \\
\text { from diverse backgrounds, cultures, and contexts. This } \\
\text { includes the capacities to feel compassion for others, } \\
\text { understand broader historical and social norms for behavior } \\
\text { in different settings, and recognize family, school, and } \\
\text { community resources and supports. }\end{array}$ & $\begin{array}{l}\text { Perspective-taking } \\
\text { Empathy } \\
\text { Appreciating diversity } \\
\text { Respect for others }\end{array}$ \\
\hline
\end{tabular}
$\begin{array}{ll}\text { Definitions } & \text { Skills }\end{array}$ 
interactions across diverse situations. This includes the capacities to consider ethical standards and safety concerns, and to evaluate the benefits and consequences of various actions for personal, social, and collective well-being.
Solving problems

Evaluating

Reflecting

Ethical responsibility

\section{Using backward design to create a new framework}

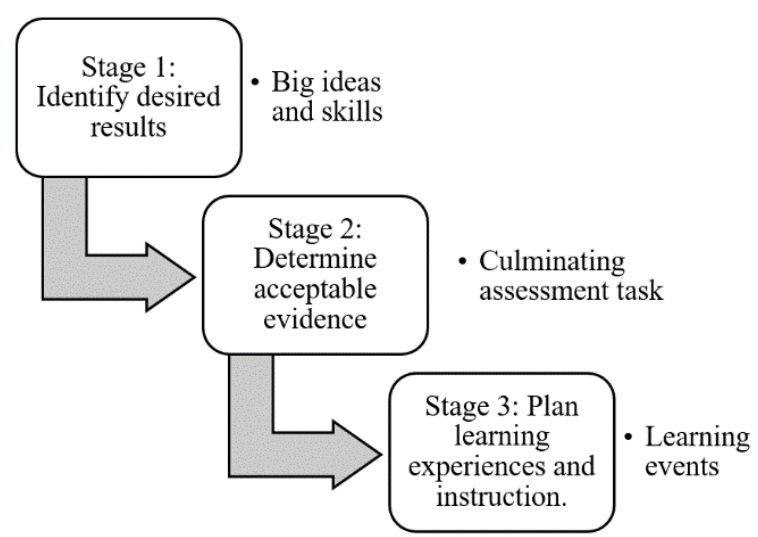

Figure 1. Backward design framework developed by Wiggins and McTighe

Backward design is a framework for instructional planning developed by Wiggins and McTighe [22]. The purpose of this framework is to consider the goals and outcomes for the learner prior to designing learning activities. Traditionally, most educators or course instructors use a "forward design" approach to instruction. In other words, they create the lesson or learning activity and then create an assessment that aligns with the content. With the backward design approach, educators first consider the specific learning targets and objectives, then they consider how the learning will be assessed, and lastly educators design learning activities that align with the assessment and learning targets. Figure 1 displays a visual of the backward design framework.

The authors of this paper propose a framework for creating a socially inclusive school environment using backward design, displayed in Figure 2. Stage 1 of the backward design framework is to identify desired results. In context of social inclusion, the desired results are based on the competencies outlined in the Collaborative for Academic, Social, and Emotional Learning (CASEL) framework for social-emotional learning in Table 1. Based on this framework, the authors propose that all students should demonstrate the ability to establish and maintain positive relationships amongst peers with or without disabilities and other forms of diversity. Stage 2 of backward design includes the determination of acceptable evidence. Traditionally, the backward design framework is implemented in context of curriculum and instructional design, in which acceptable evidence is typically determined using student assessments or permanent products. For the purpose of creating a socially inclusive environment, the authors operationalize acceptable evidence as students communicating, cooperating, and initiating social interactions with other students, including students with or without disabilities or other forms of diversity. This form of evidence is observable by the teacher or other supervising adults and has the potential to be documented through observational data collection forms such as frequency recording or duration recording [23]. Stage 3 of backward design includes planning learning experiences and instruction. These learning experiences should align with the target competencies in the socialemotional learning framework.

While there are many curriculums that teach the skills outlined in the CASEL social-emotional learning framework, it is important that instructional practices used by supervising teachers are evidence-based. Peer support arrangements [24] and other methods of systematically pairing students with and without disabilities are examples of practices that build social skills. When teaching lessons on social-emotional learning, teachers should consider the use of explicit instruction. Explicit instruction is identified as an evidence-based practice and a high-leverage practice for students with disabilities [25]. Many cognitive and emotional disabilities manifest in the form of challenges in social, communication, and other interpersonal skills [25]. For this reason, students with disabilities benefit greatly from the high level of modelling and support that is offered through explicit instruction. To ensure the successful implementation of a socially inclusive environment, all learning experiences should consider cultural, socio-economic, and other constructs of personal and systemic diversity. 


\begin{tabular}{|c|c|c|}
\hline $\begin{array}{l}\text { Step 1: Identificatin of } \\
\text { desired results }\end{array}$ & $\begin{array}{l}\text { Step 2: Determination of } \\
\text { acceptable evidence }\end{array}$ & $\begin{array}{l}\text { Step 3: Planned learning } \\
\text { experiences and } \\
\text { instruction }\end{array}$ \\
\hline $\begin{array}{l}\text { The desired results are the } \\
\text { demonstration of all } \\
\text { students establishing and } \\
\text { maintaining positive } \\
\text { relationships amongst } \\
\text { peers with or without } \\
\text { disabilities and other forms } \\
\text { of diversity. } \\
\text { Social and behavioral } \\
\text { expectations are based on } \\
\text { the CASEL social- } \\
\text { emotional learning } \\
\text { framework. }\end{array}$ & $\begin{array}{l}\text { Acceptable evidence } \\
\text { includes students } \\
\text { communicating, } \\
\text { cooperating, and initiating } \\
\text { social engagement } \\
\text { between all students with } \\
\text { and without disabilities and } \\
\text { other forms of diversity. } \\
\text { Observational forms of } \\
\text { data collection (frequency } \\
\text { recording, duration } \\
\text { recording, etc.) are } \\
\text { appropriate for } \\
\text { documenting evidence. }\end{array}$ & $\begin{array}{l}\text { The learning experience } \\
\text { considers cultural, socio- } \\
\text { economic, and other } \\
\text { constructs of personal and } \\
\text { systemic diversity. } \\
\text { Students receive socially- } \\
\text { inclusive opportunities and } \\
\text { instruction on social- } \\
\text { emotional learning and } \\
\text { cultural acceptance. } \\
\text { UDL is implimented to } \\
\text { ensure enhanced } \\
\text { accessibility and } \\
\text { engagement of all } \\
\text { students. }\end{array}$ \\
\hline
\end{tabular}

Figure 2. Framework using backward design to create a socially inclusive environment

\section{Universal Design for Learning}

Universal Design for Learning (UDL) provides a strong framework for creating inclusive schools and educational opportunities [26]. The Harvard Graduate School of Education and the Center for Applied Special Technology (CAST) developed the UDL framework in the 1990's in response to growing insight into the divergent and multiple ways people learn [26]. Much like the architectural movement of the same name, UDL emphasizes the importance of access for all learners, underscoring the three essential principles of multiple means of engagement, representation, and action and expression [27]. Similar in the way that universal design of buildings benefitting individuals with and without disabilities, UDL is an instructional framework that benefits all students by maximizing student choice, autonomy, and accessibility. Educators engage in proactive instructional planning and design with the preferences, abilities, and diversities of all of their students in mind, ensuring access and authentic inclusion is inherently present in their lessons and activities. In this way, UDL is held as a cornerstone component in inclusive education because of the emphasis on inclusion through access. Table 2 displays an overview of the 9 UDL guidelines with their corresponding checkpoints. Each guideline and checkpoint is organized under the three guiding UDL principles: Multiple means of representation, multiple means of action and expression, and multiple means of engagement.

The UDL framework has been demonstrated to be effective in improving student academic and social outcomes. A review of empirical UDL literature published in 2016 [28] found that UDL has a positive impact on student learner perceptions, teacher experience, teacher workload, and student academic outcomes across face to face, blended, and online environments. As discussed earlier in this paper, researchers found that the implementation of UDL enhanced educator's ability to address the needs of a range of diverse student needs. Furthermore, the benefits of UDL extended beyond core academics and were observed in a variety of disciplines including language learning, chemistry, and psychology [28].

\section{Conclusion}

The full inclusion of students with disabilities, and other forms of diversity, is a multi-faceted and dynamic challenge that education providers worldwide have historically struggled to conceptualize. Education providers seeking to enhance the level of social inclusion in their present educational setting can incorporate the social-emotional learning and UDL frameworks into their current practice. 
Table 2. Overview of Universal Design for Learning guidelines and checkpoints

\begin{tabular}{|c|c|c|c|}
\hline & $\begin{array}{c}\text { Multiple Means of } \\
\text { Representation }\end{array}$ & $\begin{array}{c}\text { Multiple Means of } \\
\text { Action and Expression }\end{array}$ & $\begin{array}{l}\text { Multiple Means of } \\
\text { Engagement }\end{array}$ \\
\hline Access & $\begin{array}{l}\text { 1) Provide options for } \\
\text { perception. } \\
\text { 1.1) Offer ways of customizing } \\
\text { the display of information. } \\
\text { 1.2) Offer alternatives for } \\
\text { auditory information. } \\
\text { 1.3) Offer alternatives for } \\
\text { visual information. }\end{array}$ & $\begin{array}{l}\text { 4) Provide options for } \\
\text { physical action. } \\
\text { 4.1) Vary the methods for } \\
\text { response and navigation. } \\
\text { 4.2) Optimize access to tools } \\
\text { and assistive technologies. }\end{array}$ & $\begin{array}{l}\text { 7) Provide options for } \\
\text { recruiting interest. } \\
\text { 7.1) Optimize individual } \\
\text { choice and autonomy. } \\
\text { 7.2) Optimize relevance, } \\
\text { value, and authenticity. } \\
\text { 7.3) Minimize threats and } \\
\text { distractions. }\end{array}$ \\
\hline Build & $\begin{array}{l}\text { 2) Provide options for } \\
\text { language \& symbols. } \\
\text { 2.1) Clarify vocabulary and } \\
\text { symbols. } \\
\text { 2.2) Clarify syntax and } \\
\text { structure. } \\
\text { 2.3) Support decoding of text, } \\
\text { mathematical notation, and } \\
\text { symbols. } \\
\text { 2.4) Promote understanding } \\
\text { across languages. } \\
\text { 2.5) Illustrate through multiple } \\
\text { media. }\end{array}$ & $\begin{array}{l}\text { 5) Provide options for } \\
\text { expression \& communication. } \\
\text { 5.1) Use multiple media for } \\
\text { communication. } \\
\text { 5.2) Use multiple tools for } \\
\text { construction and composition. } \\
\text { 5.3) Build fluencies with } \\
\text { graduated levels of support for } \\
\text { practice and performance. }\end{array}$ & $\begin{array}{l}\text { 8) Provide options for } \\
\text { sustaining effort \& } \\
\text { persistence. } \\
\text { 8.1) Heighten salience of goals } \\
\text { and objectives. } \\
\text { 8.2) Vary demands and } \\
\text { resources to optimize } \\
\text { challenge. } \\
\text { 8.3) Foster collaboration and } \\
\text { community. } \\
\text { 8.4) Increase mastery-oriented } \\
\text { feedback. }\end{array}$ \\
\hline Internalize & $\begin{array}{l}\text { 3) Provide options for } \\
\text { comprehension. } \\
\text { 3.1) Activate or supply } \\
\text { background knowledge. } \\
\text { 3.2) Highlight patterns, critical } \\
\text { features, big ideas, } \\
\text { and relationships. } \\
\text { 3.3) Guide information } \\
\text { processing and visualization. } \\
\text { 3.4) Maximize transfer and } \\
\text { generalization. }\end{array}$ & $\begin{array}{l}\text { 6) Provide options for } \\
\text { executive functions. } \\
\text { 6.1) Guide appropriate goal } \\
\text { setting. } \\
\text { 6.2) Support planning and } \\
\text { strategy development. } \\
\text { 6.3) Facilitate managing } \\
\text { information and resources. } \\
\text { 6.4) Enhance capacity for } \\
\text { monitoring progress. }\end{array}$ & $\begin{array}{l}\text { 9) Provide options for self- } \\
\text { regulation. } \\
\text { 9.1) Promote expectations and } \\
\text { beliefs that } \\
\text { optimize motivation. } \\
\text { 9.2) Facilitate personal coping } \\
\text { skills and strategies. } \\
\text { 9.3) Develop self-assessment } \\
\text { and reflection. }\end{array}$ \\
\hline Goal & $\begin{array}{l}\text { Expert learners who are } \\
\text { purposeful \& motivated }\end{array}$ & $\begin{array}{l}\text { Expert learners who are } \\
\text { resourceful \& knowledgeable }\end{array}$ & $\begin{array}{l}\text { Expert learners who are } \\
\text { strategic \& goal-directed }\end{array}$ \\
\hline
\end{tabular}

Note. Adapted from "Universal Design for Learning Guidelines version 2.2" by CAST (2018). Retrieved from http://udlguidelines.cast.org

Education leaders seeking to initiate new programs or explore novel models of providing education should consider full inclusion and the benefits it provides all students. By using backward design to plan ahead and intentionally design educational environments to be inclusive and support the social-emotional needs of all students, education providers can construct new realities and dismantle disabling barriers that were first constructed by society.

\section{References}

[1] Wehmeyer, M. L.(2013). The Story of Intellectual Disability, Paulh Brooks Publishing co, Baltimore, MD.

[2] Silverman, W., Miezejeski, C., Ryan, R., Zigman, W., Krinsky-McHale, S., \& Urv, T. (2010) 'Stanford-Binet and WAIS IQ differences and their implications for adults with intellectual disability (aka mental retardation)'. Intelligence, 38(2), pp. 242-248. https://doi.org/10.1016/j.intell.2009.12. 005 . 
[3] Zenderland, L. (1999) Measuring minds : Henry Herbert Goddard and the origins of American intelligence testing, Cambridge: Cambridge University Press.

[4]United Nations Educational, Scientific and Cultural Organization. (1994) The Salamanca Statement and Framework for Action on Special Needs Education. https://unesdoc.unesco.org/ark:/48223/pf0000098427

(Access date: 14 May, 2020).

[5] United Nations Educational, Scientific and Cultural Organization. (2016) Education 2030 Incheon Declaration and Framework for Action. http://uis.unesco.org/sites/ default/files/documents/education-2030-incheon-frameworkfor-action-implementation-of-sdg4-2016-en_2.pdf (Access date: 12 May, 2021).

[6] United Nations Educational, Scientific and Cultural Organization (2020). Towards Inclusion in Education: Status, trends and challenges, The UNESCO Salamanca Statement 25 years on. UNESCO; Paris. https://unesdoc.unesco.org/ark: /48223/pf0000374246 (Access date: 23 March, 2020).

[7] Brown v. Board of Education of Topeka, 347 U.S. 483 (1954).

[8] Osgood, R. L. (2005). The History of Inclusion in the United States, Gallaudet University Press, Washington, DC.

[9] Rehabilitation Act of 1973, 93-112, 29 U.S.C. (1973).

[10] Education For All Handicapped Children Act, 94-142, 89 Stat. 773 (1975).

[11] Individuals with Disabilities Education Improvement Act of 2004, 108-446, 118 Stat. 2647 (2004).

[12] Biklen, D. (2020) 'Presuming Competence, Belonging, and the Promise of Inclusion: The US Experience,' Prospects, 49(3), pp. 233-247.

[13] Connor, D. J., \& Berman, D. (2019) '(Be)longing: A Family's Desire for Authentic Inclusion,' International Journal of Inclusive Education, 23(9), pp. 923- 936. https://doi.org/10.1080/13603116.2019.1602361_(Access date: 1 May, 2020).

[14] Kirby, M. (2017) 'Implicit Assumptions in Special Education Policy: Promoting Full Inclusion for Students with Learning Disabilities', Child \& Youth Care Forum, 46(2), 175-191. https://doi.org/10.1007/s10566-016-9382-x

(Access date: 12 May, 2020).

[15] Goodley, D. (2014) Dis/ability studies: Theorising Disablism and Ableism, Routledge.

[16] Shakespeare, T. (2006) 'The Social Model of Disability,' The Disability Studies Reader, 2, pp. 197-204.
[17] United Nations Educational, Scientific and Cultural Organization [UNESCO] (2020b). Inclusion and Education: All means All. UNESCO: Paris. https://en.unesco.org/gemreport/report/2020/inclusion (Access date: 28 April, 2020).

[18] Hehir, T., Grindal, T., Freeman, B., Lamoreau, R., Borquaye, Y., \& Burke, S. (2016) A summary of the Evidence on Inclusive Education, Instituto Alana: Sao Paulo.

[19] Odden, A. R., \& Picus, L. O. (2008) School Finance: A Policy Perspective (4th ed.). McGraw-Hill: New York.

[20] Collaborative for Academic, Social, and Emotional Learning [CASEL]. (2020) 'CASEL's SEL framework: What are the core competence areas and where are they promoted?' https:/casel.org/wp-content/uploads/2020/10/CASEL-SELFramework-10.2020-1.pdf (Access date: 15 February, 2020).

[21] Bandura, A., \& McClelland, D. C. (1977) Social learning theory, Prentice Hall: Englewood cliffs.

[22] Wiggins, G., \& McTighe, J. (2005). Understanding by design, ASCD, Alexandria, VA.

[23] Barry, C., Walker, J. D. (2020). Behavior Management: Systems, Classrooms, and Individuals, Plural Publishing, San Diego, CA.

[24] Carter, E. W., Moss, C. K., Asmus, J., Fesperman, E., Cooney, M., Brock, M. E., Lyons, G., Huber, H. B., \& Vincent, L. B. (2015). 'Promoting Inclusion, Social Connections, and Learning Through Peer Support Arrangements', Teaching Exceptional Children, 48(1), 9-18. https://doi.org/10.1177/0040059915594784

[25] McLeskey, J., Barringer, M.-D., Billingsley, B., Brownell, M., Jackson, D., Kennedy, M., Lewis, T., Maheady, L., Rodriguez, J., Scheeler, M. C., Winn, J., \& Ziegler, D. (2017). High-leverage practices in special education, Council for Exceptional Children \& CEEDAR Center, https://ceedar.education.ufl.edu/wp-content/uploads/ 2017/07/CEC-HLP-Web.pdf (Access date: 12 March, 2020).

[26] Center for Applied Special Technology [CAST]. (2020) 'Timeline of Innovation,' CAST; https://www.cast.org/impa ct/timeline-innovation (Access date: 13 February, 2020).

[27] Center for Applied Special Technology [CAST]. (2018) 'Universal Design for Learning Guidelines Version 2.2,'

CAST; http://udlguidelines.cast.org (Access date: 1 April, 2020).

[28] Al-Azawei, A., Serenelli, F., \& Lundqvist, K. (2016). 'Universal Design for Learning: A Content Analysis of PeerReviewed Journal Papers from 2012 to 2015', Journal of the Scholarship of Teaching and Learning, 16(3), 39-56. 